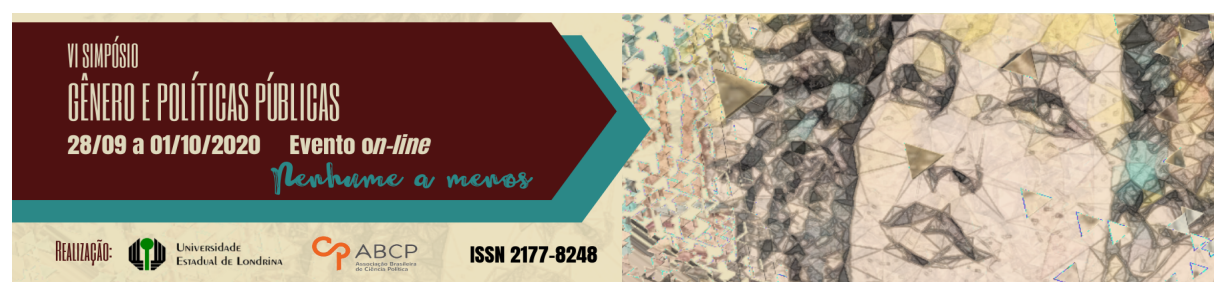

\title{
Percursos profissionais de docentes universitárias negras
}

\author{
Letícia Laureano dos Santos ${ }^{1}$
}

\section{Resumo}

As políticas públicas - como a Lei $\mathrm{n}^{\circ} 12.711 / 2012$, conhecida como a lei das cotas - buscam assegurar e ampliar a presença de afrodescendentes no ensino superior. Contudo, as desigualdades de acesso à educação continuam sendo uma realidade para a população negra. Neste sentido, a presente investigação analisa os percursos profissionais de docentes universitárias negras, enfatizando as relações entre educação, trabalho e etnia. Neste intuito foi desenvolvida pesquisa qualitativa, de característica exploratória, tendo como instrumento de coleta de dados entrevistas com duas professoras negras que atuam no ensino superior, posteriormente analisadas sob a perspectiva hermenêutica. As entrevistadas tiveram percursos semelhantes: precisaram conciliar educação e trabalho durante a trajetória acadêmica e a docência universitária tornou-se objetivo profissional após o ingresso na pósgraduação. As docentes revelam que seus percursos são marcados pela dupla discriminação - de raça e gênero - sendo suas presenças valorizadas por colegas e estudantes afrodescendentes.

Palavras-chave: docência; ensino superior; mulheres negras.

\section{Professional trajectories of black university professors}

\begin{abstract}
The public policies - such as Law $\mathrm{n}^{\mathrm{o}} 12.711 / 2012$, known as the quota law seek to ensure and expand the presence of african descent people in higher education. However, inequalities in access to education remain a reality for

1 Universidade LaSalle, mestranda em educação, e-mail: letthy81@gmail.com.

GT 09 - Gênero e relações étnico-raciais: as desigualdades e os desafios contemporâneos
\end{abstract}


the black population. Therefore, the investigation analyzes the professional trajectories of black women university professors, emphasizing the relationship between education, work and ethnicity. For this purpose, a qualitative research, with an exploratory characteristic, was developed, using as a data collection instrument interviews with two black professors who work in higher education, later analyzed from a hermeneutic perspective. The interviewees had similar trajectories: they had to reconcile education and work during the academic trajectory and university teaching became a professional objective after entering graduate school. The professors reveal that their paths are marked by double discrimination - race and gender - and their presence is valued by colleagues and african descent students.

Keywords: black women; higher education; professor.

\section{Introdução}

O mundo do trabalho passou por transformações significativas, principalmente no século $X X$. $O$ avanço das tecnologias de informações, novos arranjos nas relações de trabalho e a presença feminina cada vez mais presente em diversos espaços que no passado eram predominantemente masculinos são alguns exemplos das mudanças ocorridas. No entanto, conforme salientam Munanga e Gomes (2016) apesar das transformações nas condições de vida e papel das mulheres em todo o mundo, especialmente a partir dos anos 60, as mulheres negras continuam vivendo uma situação marcada pela dupla discriminação: ser mulher em uma sociedade machista e ser negra numa sociedade racista.

Ribeiro (2019) assinala que potenciais talentos acabam por não serem descobertos ou desenvolvidos em consequência do racismo estrutural. A situação se torna mais grave para mulheres negras que muitas vezes são destinadas ao subemprego. Contudo, se no passado as mulheres negras foram trabalhadoras escravizadas e objeto sexual de seus exploradores, hoje elas podem ser vistas como referência ano combate à discriminação racial e estão presentes em diversos espaços, entre eles a academia. 


\section{Mulheres negras e o mundo do trabalho}

Embora tenha se passado mais de um século do fim da escravidão negra, o mundo trabalho ainda reproduz a lógica de segregação e exploração para muitas mulheres negras. Davis (2016) aponta que o espaço que o trabalho ocupa hoje na vida de muitas mulheres negras ainda reproduz um padrão estabelecido no período de escravidão. No passado escravista, enquanto os homens sofriam punições que consistiam em açoitamentos e mutilações; as mulheres além de serem açoitadas e mutiladas, também eram estupradas. Para os colonizadores, o estupro era uma expressão de domínio econômico e controle do proprietário em relação as suas escravas na condição de trabalhadoras.

Schumaher e Brazil (2007) afirmam que no Brasil as mulheres negras escravizadas também eram exploradas sexualmente pelos colonizadores. Aquelas que trabalhavam na casa-grande se tornavam vítimas de estupro e assédios constantes, sendo obrigadas a viver como concubinas de seus senhores. Nota-se desta forma que a exploração da força de trabalho e os abusos sexuais eram uma prática comum por parte dos colonizadores nos dois países.

Davis (2016) salienta que após o período escravista, muitas mulheres negras permaneceram trabalhando no campo. Para as demais, as únicas alternativas eram trabalhos como lavar roupas em casa para famílias brancas ou realizar serviços domésticos variados para uma única família branca. Ou seja, era difícil escapar da lógica do campo, cozinha ou lavanderia. Mesmo com o surgimento dos movimentos feministas, muitos dos discursos de lutas contemplavam apenas as mulheres brancas abastadas. Conforme explicita Davis (2016), os programas das feministas de classe média do passado e do presente se mostravam coniventes com a omissão dos problemas dessas trabalhadoras em geral, sendo uma justificativa velada para a exploração de suas próprias empregadas. 
Desta forma, Munanga e Gomes (2016) defendem que apesar da saída das mulheres do ambiente doméstico para ocupar os espaços do mercado de trabalho ser considerada uma realidade recente, as mulheres negras há tempos tem ocupado espaços fora de suas casas para que outras mulheres não negras possam cumprir seus compromissos no mercado de trabalho.

Apesar das reinvindicações dos movimentos feministas pela igualdade de diretos e ocupação de diferentes espaços por todas as mulheres, é inegável que as particularidades na realidade das mulheres negras não eram consideradas neste discurso universal.

Conforme explica Carneiro (2003), o não reconhecimento das sequelas do racismo e da discriminação racial nos processos de seleção e alocação da mão-de-obra feminina, mesmo em situações em que as mulheres negras possuem qualificação e formação necessárias aos cargos, tornou insustentável manter o discurso feminista universal. Particularmente para as mulheres negras, o quesito "boa aparência" se torna uma forma sutil de barrar as aspirações no mercado de trabalho. É possível perceber que apesar dos avanços das mulheres obtidos graças às lutas dos movimentos feministas na ocupação de espaços sociais, as mulheres negras ainda precisam enfrentar as barreiras da discriminação e preconceito racial.

Sobre a presença das mulheres negras no mercado de trabalho, Ribeiro (2018) defende que são poucos os empregadores que contratam mulheres negras para as suas vagas. Embora as mulheres tenham ultrapassado as barreiras da discriminação de gênero em diversos espaços sociais, muitas mulheres negras ainda são submetidas à condição de trabalho precário ou não estão presentes em ambientes considerados de status social por conta da discriminação racial.

\section{Educação para ultrapassar as barreiras da discriminação racial}


Ao longo da história moderna, a população negra precisou e ainda precisa ultrapassar as barreiras impostas pelo racismo. Uma destas barreiras é o estigma social de que a população negra possui menor capacidade intelectual e que por este motivo, se encontra em situação de desigualdade social. Conforme argumenta Davis (2016), durante muito tempo se acreditou na ideologia dominante que afirmava que a população negra era incapaz de progressos intelectuais. No entanto, a pesquisadora pondera que se negros e negras fossem de fato inferiores em termos biológicos e intelectuais, jamais teriam manifestado desejo nem capacidade de adquirir conhecimento.

De acordo com Gomes (2010) o estereótipo de inferioridade da população presente no cotidiano social e educacional é o reflexo de algo construído historicamente e sofre um processo de retroalimentação, reforçando e legitimando as práticas racistas presentes no imaginário social. Gonçalves e Silva (2000) explicitam que no período pós-abolição, a população negra se depara com o abandono, continuando em condição de desigualdade, pois a necessidade de trabalhar afastava homens e mulheres dos bancos escolares. Diante da ausência de políticas de inclusão educacional desta população, negros e negras passaram a se articular através da criação de entidades que visavam a alfabetização dos adultos e promoção de uma formação mais completa para as crianças negras.

Conforme Gomes (2012) a educação sempre foi uma das pautas das entidades negras ao longo da sua trajetória. $O$ acesso ao desenvolvimento educacional é visto pelo Movimento Negro como um direito daqueles que lutam pela democracia e como uma possibilidade de ascensão social. Munanga e Gomes (2016) enfatizam que as políticas universais de acesso à educação, implementadas durante o século XX não foram suficientes para alterar as desigualdades raciais na educação brasileira.

Além das dificuldades de acesso à educação, o racismo e a discriminação produzem efeitos sutis, porém perversos nas práticas de 
ensino. Silva e Gomes (2007) explicitam que apesar da diversidade étnico-racial ser uma característica marcante da sociedade brasileira, de forma contraditória ela é por muitas vezes ignorada nos espaços educacionais. A presença da diversidade, a não segregação e não discriminação das diferenças ainda é uma postura política e profissional ausente em muitas práticas pedagógicas das escolas. Ribeiro (2018) declara que apesar da lei 10.639/2003 que estabelece diretrizes e bases para inclusão no currículo da rede de ensino público da temática "História e Cultura Afro-Brasileira", é evidente a não aplicação por parte dos educadores, mostrando mais uma nuance do racismo estrutural que invisibiliza a tomada de consciência da contribuição histórica da cultura afro-brasileira, reforçando as práticas discriminatórias.

Os impactos do racismo também podem ser percebidos na educação de nível superior. Conforme dados do Censo da educação superior de 2018, apenas 6,9\% do total de matriculas realizadas nos cursos de graduação presenciais e a distancia são de estudantes que se autodeclaram negros, seguidos de $28,8 \%$ de estudantes pardos e $41,8 \%$ de autodeclarados brancos. Nota-se através destes dados que há uma diferença expressiva entre o percentual de estudantes negros e brancos, sendo mais um indicativo da presença do racismo estrutural na sociedade brasileira.

Conforme Silva e Euclides (2018) é importante observar que existe uma situação característica acerca das mulheres negras no espaço científico. Se por um lado, as mulheres são maioria no universo acadêmico nos anos iniciais, quando se chega aos graus superiores, nota-se pouca ou quase nenhuma presença de acadêmicas afrodescendentes. Neste sentido, Ribeiro (2017) destaca a importância das ações afirmativas e da presença das mulheres negras na academia. Para a pesquisadora, ocupar este espaço permitirá que as pesquisadoras negras constatem a partir de suas realidades e vivências, as anomalias existentes em determinados fenômenos sociais, que por vezes são distorcidas, ignoradas ou ocultadas. Este lugar social 
ocupado pelas mulheres negras pode trazer um novo olhar à questões sempre existentes, possibilitando outras problematizações. Ocupar espaços de produção de conhecimento tem sido uma estratégia de resistência para as mulheres negras. Hooks (2019) explica que assumir a negritude como resistência política cria condições necessárias para negros e negras se articulem coletivamente contra as forças de dominação e morte que tomam as vidas negras.

\section{Percurso investigativo}

Esta investigação que possui enfoque qualitativo, de nível exploratório, visando analisar as relações entre educação, trabalho e etnia, analisando os percursos de vida de professoras universitárias negras. A pesquisa tem como universo professoras negras que atuam em instituições de nível superior, na faixa etária entre 30 e 45 anos, que residem na região metropolitana de Porto Alegre. A amostra é escolhida por conveniência, a partir de contatos profissionais e pessoais da pesquisadora, tendo como Critérios de inclusão ser negra, ser professora de instituição de nível superior e ser residente na região metropolitana de Porto Alegre. As entrevistadas possuem formação em Ciências Contábeis e Pedagogia e atuam em instituições privadas. A coleta de dados foi feita a partir de entrevista e, no tratamento do material advindo das entrevistas, foi desenvolvida a análise sob a perspectiva hermenêutica, a partir de histórias de vida. De acordo com Hermann (2003), a hermenêutica tem como foco o pensar e o conhecer para a vida prática, se opondo à crença de uma realidade totalmente objetiva. Além disso, este tipo de análise considera a perspectiva do interpretar, da produção de sentido e da impossibilidade de separar o sujeito do mundo objetivado. Para realização da análise serão examinadas três perspectivas de estudo trajetória educacional, mundo do trabalho e docência na educação de nível superior. 


\section{Docentes universitárias negras: percursos e trajetórias}

Nesse momento são apresentadas as participantes da investigação, a partir de entrevistas gravadas e, posteriormente, transcritas e analisadas. Os nomes das participantes, pessoas e instituições citadas nas entrevistas foram alterados, a fim de preservar as suas identidades. A seguir são apresentadas as entrevistadas:

Jamila, 42 anos, formada em Ciências Contábeis, Mestrado em economia e especialização em psicopedagogia. Atua como docente de cursos de graduação e pós-graduação de instituições de ensino privadas.

Niara, 34 anos, com formação em Pedagogia Multimeios e Informática Educativa, Mestrado em educação, especialização em Docência no Ensino Superior , especialização em Gestão Educacional. Atua como professora/tutora de cursos de graduação na modalidade à distância de instituição de ensino privada.

As entrevistadas foram convidadas a partilhar com as pesquisadoras as suas histórias de vida, sendo que no decorrer da escuta, foram indagadas a partir de elementos como discriminação, raça e gênero. A partir do relato das participantes, foram estabelecidas categorias de análise que buscam elucidar a questão de pesquisa, partindo dos seguintes elementos: trajetória educacional, mundo do trabalho, e docência na educação superior, apresentadas a seguir.

\section{Trajetória educacional}

As duas participantes trouxeram elementos de sua formação básica em escola pública quando convidadas a compartilhar suas histórias de vida. Niara comenta que na escola em que estudou havia problemas como falta de professores, desvalorização docente, desrespeito por parte dos alunos, o que a seu ver comprometiam a qualidade do ensino: 
Eu vim de uma escola pública, onde os alunos não respeitavam professor e eu via o quanto o professor era desvalorizado e o quanto os professores faltavam na escola estadual. Eu sempre achei aquilo péssimo, fiquei numa escola bem longe da minha casa em razão dos amigos [...]Eu me arrependi muito de ter permanecido naquela escola. Uma escola muito fraca, não por ser estadual. Mas aquela escola, enfim, muito fraca e não nos estimulava muito a crescer.

Este fato é lembrado por Niara ao comentar sobre as suas tentativas de ingresso em uma universidade federal após concluir o ensino médio. Esta fala pode indicar a sua percepção sobre a influência de sua formação básica em uma escola pública ao não ingresso em uma universidade federal. Ribeiro (2018) comenta que um estudante negro que estudou em uma escola pública com baixa qualidade de ensino dificilmente terá as mesmas chances de ingresso de um estudante de classe média que estudou em uma boa escola. A pesquisadora sustenta que esta é uma das nuances do racismo institucional, que impede a mobilidade social e o acesso da população negra a esses espaços.

Jamila relembra que foi alfabetizada pela mãe antes de ingressar na educação básica. Ela comenta que sempre teve bastante facilidade de aprendizado e gostava de ensinar outras crianças, inclusive as mais velhas. A participante lembra que fora do horário de aula ensinava várias crianças em sua casa e que também ajudou a alfabetizar algumas pessoas. Quando passa a ter disciplinas específicas na escola (a partir da antiga quarta série) ela comenta que começa a "cobrar" pelas aulas particulares, o que para ela pode ter despertado o seu interesse pela área financeira:

Quando iniciaram as matérias na quarta série, eu comecei a dar aula particular em troca de chocolates (risos) Eu acho que a questão das finanças já estava lá e não achava justo dar aula de graça (risos) Então eu cobrava e era uma barra de chocolate (risos). Dava aula para os que ficavam em recuperação em troca de chocolate, por muito tempo eu fiz isso (risos). 
Sobre o fato de Jamila com pouca idade já demonstrar interesse em aprender e compartilhar conhecimentos Hooks (2013) afirma que a população negra aprende desde a infância que o interesse pelos estudos e à vida intelectual é um ato de resistência à hegemonia branca. O estímulo da mãe da participante pela alfabetização antes do ingresso na escola e interesse por compartilhar os seus conhecimentos podem indicar uma consciência da importância da educação para o seu desenvolvimento intelectual.

As entrevistadas também comentam sobre as escolhas de formação profissional ao concluírem a educação básica. Jamila explica que inicialmente pensou na área de tecnologia da informação (TI), mas após assistir a uma palestra em uma instituição de ensino profissionalizante, surgiu o interesse na área contábil.

Na verdade minha opção inicial era na área de T.I. Eu fiz um curso na instituição $X$ enquanto eu ainda estava fazendo cursinho pré- vestibular. Nesse curso teve uma palestra de um contador que na época era presidente do conselho de contabilidade e eu fiquei apaixonada por aquilo, com tudo que ele falou. Eu fiquei apaixonada por aquilo e pensei: "Não, eu vou trocar e a minha opção vai ser fazer contabilidade" Ir para essa área por que eu sempre gostei de números. Eu pensava assim: "eu que sempre gostei de números, vou mexer com dinheiro, é isso que eu quero." E essa foi a minha ideia inicial.

Após frequentar aulas do curso pré-vestibular, Jamila conta que prestou vestibular para uma universidade federal e foi aprovada, ingressando no curso de Ciências Contábeis. Niara conta que também tentou ingressar em na universidade federal. Após várias tentativas sem conseguir a classificação necessária para o ingresso, optou por uma instituição privada.

Quando eu fiz vestibular, na época fazíamos muitos vestibulares. Não só da federal, mas eu sempre tentava (federal), tentei por um tempo, desde dezessete, dezoito anos, fiz vestibular para fisioterapia e fazia para publicidade e propaganda. Tudo a ver, né?(risos) Uma era da área da saúde e outra da comunicação. É que na 
época fisioterapia era uma profissão da moda, então eu queria muito ser. Mas enfim, eu não passei. Eu tentei publicidade e também não passei. Então foi na minha segunda opção para fisioterapia que eu entrei em uma instituição privada, que era muito perto da minha casa, era administração hospitalar.

Niara afirma que um dos seus objetivos era cursar a faculdade de fisioterapia em uma universidade pública, tendo como segunda opção o curso de administração hospitalar em uma universidade privada. Ribeiro (2018) assinala que o racismo estrutural é revelado quando a população negra tem maiores dificuldades para ocupar determinados espaços, pois estudante negro oriundo de uma escola pública poderá ter poucas chances de ingresso em uma universidade pública. Niara relata que após o ingresso na universidade privada, não se adaptou à instituição e ao curso escolhido, sentindo as diferenças sociais entre ela e seus colegas, que tinham maior poder aquisitivo. Desta forma, ela toma a decisão de interromper o curso e ingressar em um curso técnico gratuito.

Eu detestei o curso, não era aquilo que eu queria, mas eu gostei da parte da gestão. Não era a questão da negritude, eu tenho essas amizades até hoje, a turma era bastante mista, de etnia, muitos negros na turma. Mas na questão social eu me sentia diferenciada, porque as meninas e os guris tinham um poder aquisitivo mais alto que o meu. Eu tranquei o curso, não gostei, enfim, fui fazer um curso técnico, que era de graça.

O sentimento relatado por Niara pode relacionar-se com o que observam Munanga e Gomes (2016). Para eles, a forma institucional de segregação de pessoas negras é percebida de forma sutil. Elas se manifestam sob a forma de isolamento dos negros em determinados locais, instituições e empregos. Portanto, a opção de Niara por não concluir o curso em uma instituição privada e ingressar em um curso técnico público pode sugerir que de alguma forma a participante sentiu-se excluída em um ambiente acadêmico elitizado. É importante observar que a participante não ingressou no curso que inicialmente 
era do seu desejo, o que também pode ter sido determinante na sua decisão. No entanto, o ingresso no curso técnico em secretariado e o contato com a disciplina de informática despertaram o interesse no curso superior que posteriormente ela viria a cursar.

Tinham várias disciplinas e uma delas era informática. A professora de informática era péssima (risos), ela pedia as atividades e não ensinava ninguém a fazer nada. Ela só exigia e as meninas não sabiam realizar as tarefas, só que eu já tinha feito vários cursos de informática. [...] Eu começava a ajudar uma, ajudar outra [....] Eu comecei a fazer amizade com a professora e eu disse: "professora, eu posso ensinar as gurias como se faz tal formatação?" Ela disse: "pode, não tem problema." E eu comecei a gostar daquilo, uma docência para adultos, envolvendo tecnologia, isso me interessou. Fui fazendo o curso técnico, as provas e aquilo me amadureceu muito, mas eu vi que não era mais aquilo que eu queria (secretariado). Pesquisando eu encontrei em uma instituição privada o curso de Pedagogia em Multimeios e Informática Educativa e me apaixonei.

Niara explica que após a conclusão do curso técnico, prestou vestibular para o curso de Pedagogia em Multimeios e informática educativa em uma instituição privada. A participante comenta que foi uma experiência bem diferente da vivenciada na faculdade anterior, pois além de ingressar no curso que era do seu desejo, também se identificou com o curso e colegas de turma: "Eu me apaixonei pelo curso! E quando eu entrei, nas primeiras disciplinas, a estrutura das pessoas, metade da turma tinha magistério, a outra metade não tinha e eu me apaixonei!"

Jamila e Niara também comentam sobre suas trajetórias na pósgraduação. Niara conta que atuava em uma instituição em que não se sentia valorizada, vendo a necessidade de realização de uma pósgraduação para que assim pudesse ter outras oportunidades profissionais. Conversando com uma amiga que havia sido colega de universidade, soube da especialização em docência na educação superior. Ao consultar o currículo do curso, ficou animada como a 
possibilidade de atuar em uma instituição de ensino superior após concluir o curso.

Ela me mandou o currículo, me apaixonei, é isso que eu quero! Eu quero atuar com o ensino superior. Mas já sabia que teria que fazer mestrado, enfim. E a cada disciplina fui me apaixonando mais, me dedicando $e$ aprendendo a atuar com o ensino superior, alguns professores maravilhosos, outros deixavam a desejar, como tudo, nem tudo é maravilhoso. Mas a instituição em si, eu estava gostando muito e fazendo a pós-graduação eu descobri que tinha graduação EAD e era tutoria.

Niara possui experiência na Educação à Distância (EAD) e por isso vislumbrou uma oportunidade como professora/tutora de instituições que possuam cursos nesta modalidade de ensino. Além de especializações, Niara também cursou Mestrado em Educação em uma universidade do exterior na modalidade à distância, despertando ainda mais o seu interesse no ensino superior EAD. Jamila relata que após ter passado um período vivendo no exterior, ao retornar foi em busca de informações sobre ingresso no mestrado na universidade em que se graduou. Realizou o processo seletivo e ingressou no Mestrado em Economia.

Quando eu ingressei, o Professor Marcelo, que tinha sido meu professor e na época era coordenador do curso de Contábeis, disse pra mim: "você não tem vontade de dar aula?" Foi no dia que eu ia fazer a minha matricula no mestrado, e eu disse para ele: "olha, penso nisso" e ele: "vamos conversar um pouquinho então."

Niara relata que a conversa com o seu professor despertou o interesse na docência universitária. Percebe-se no relato das duas participantes que o ingresso na pós-graduação impulsionou-as na busca de uma carreira docente. De acordo com Marques (2018) a presença de negros e negras ambientes considerados elitizados contribui para o fortalecimento étnico-racial de jovens negros e os motiva a vislumbrarem a ocupação de espaços considerados socialmente brancos, como a academia. Ribeiro (2018) assinala que 
mesmo sendo a maioria no Brasil, a presença da população negra ainda é pequena na academia. A pesquisadora observa que racismo institucional existente na sociedade brasileira tem impedido a mobilidade social e o acesso da população negra a esses espaços.

\section{Mundo do trabalho}

As duas participantes contam sobre as experiências profissionais oportunizadas através de estágios ou programas vinculados à universidade. Niara explica que após o ingresso na universidade, foi em busca de oportunidades de estágio: "Na medida em que ia aprendendo, logo fui procurar um estágio, fui para a escola pública e me apaixonei mais ainda, aprendi muito" Ela também destaca que foi por meio de um contato com um profissional que realizou uma atividade onde realizava estágio que surgiu uma oportunidade de emprego.

Ele foi procurar nossa coordenação, para ajudar ele na parte didática, por que ele era da área da gestão, enfim, me apaixonei e aí eu peguei o e-mail dele e nisso a gente começou a trocar e-mails. E num desses e-mails ele disse: "olha, eu to saindo daquele meu trabalho, eu sou educador social, se você quiser vir pra minha vaga, se quiser conhecer o meu trabalho, a vaga é sua e é carteira assinada." Era para atuar com trabalho educativo e com o SASE (Secretaria de Articulação com os Sistemas de Ensino). Eu fiz a entrevista com a coordenação, a coordenação gostou de mim e eu fui contratada.

Jamila relata que enquanto ainda estava na universidade, participou de um programa de trainee, onde permaneceu por cerca de seis anos. Após esta experiência, surgiram outras oportunidades na sua área de formação.

No ano de 99 eu ingressei naqueles programas de trainee [...] trabalhei por seis anos lá. Em seguida em entrei em outra empresa de auditoria e trabalhei quase dois anos, não chegou bem a dois anos. Eu entendi que eu precisava 
trabalhar em algo que me ocupasse menos tempo, estava bem dificil pra mim, trabalhar em auditoria, estar sempre viajando, trabalhar final de semana, até tarde.

A participante comenta que após a saída da empresa de auditoria onde permaneceu por quase dois anos, surgiu uma oportunidade para morar no exterior. Ela conta que por possuir experiência em empresas multinacionais e domínio da língua inglesa recebeu uma oportunidade para atuar como supervisora em uma rede de supermercados. "Foi uma experiência muito legal. A Nova Zelândia recebe pessoas do mundo inteiro, então eu tinha colegas indianos, russos, irlandeses, enfim. Cada um com o seu sotaque e a gente se entendia em inglês. Foi uma experiência bem legal."

Ao serem questionadas sobre a influência de serem mulheres e negras em suas trajetórias profissionais, as participantes demonstram percepções distintas. Niara revela não ter percebido impacto em relação a gênero e raça na sua trajetória. Jamila confirma esta influência na busca de oportunidades em determinados espaços. Porém, tanto Niara quanto Jamila apresentam em seus relatos episódios de discriminação.

Niara conta que em uma escola privada considerada exigente, sentiu discriminação vinda das crianças: "Eles estavam acostumados com a professora da manhã e a coordenadora, que eram brancas e chegando lá, viam uma negra da minha estrutura. No inicio sofri, sim, um pouco de preconceito por algumas crianças, pais e freiras, que eram as nossas coordenadoras". Ela afirma que apesar dos episódios de discriminação ocorridos na escola, esta foi uma experiência profissional de muito aprendizado. Além da experiência de sala de aula, nesta escola teve contato com os softwares educativos, o que para ela foi importante para a sua formação. No entanto, ela comenta que a exigência sentida naquela escola privada deixou-a desmotivada: "aquilo me afastou um pouco, eu não curti muito aquela parte. Eu fiquei doente na época e daí saí de lá". 
Niara menciona outro episódio ocorrido em outra instituição em que atuou após a saída da escola mencionada anteriormente:

De lá, eu fui para outra escola privada, que era faculdade e escola próximas. Não senti preconceito dos alunos nem dos professores, mas quando surgiu uma vaga para efetivação eu senti preconceito por parte da coordenação. Mesmo com mais experiência que as meninas que estavam ali, eu não fui à frente da vaga para efetivação. Nem tinha muito a ver com a nossa área, na verdade era para ser auxiliar de biblioteca, mas é claro que eu queria carteira assinada para conseguir pagar a faculdade.

Munanga e Gomes (2016) declaram que o preconceito racial existente no Brasil revela um sistema social racista que possui mecanismos para reproduzir as desigualdades raciais. Os pesquisadores apontam que a discriminação racial e a segregação da população negra em determinados espaços podem ser consideradas práticas do racismo e a concretização do preconceito.

Sobre as experiências de discriminação no mundo do trabalho, Jamila conta que elas se manifestam de várias formas. "Eu vou contar o que acontece: você está frequentando lugares em que as pessoas, a maior parte das pessoas, pensam que não é para você estar ali, aquilo irrita muito. Como se fosse uma ofensa você estar ali." Sobre as situações vivenciadas na sua trajetória profissional, Jamila faz o seguinte relato:

Quando elas não conseguem falar a respeito de você, do seu trabalho, da sua trajetória, você ganha outros adjetivos. Então os seus adjetivos são: "ah, você é muito petulante!" Mudam os adjetivos, mas você sabe que aquilo tem a ver com a sua cor. Ou então falam: "vocêé forte demais". Começam os superlativos.

Sobre as atitudes vivencias pelas mulheres negras em uma sociedade racista, Ribeiro (2018) aponta que uma mulher negra em posição de poder causa desconforto em determinados ambientes e espaços em que ocupa. As manifestações de discriminação são manifestadas através de olhares e comentários dirigidos para aquelas que não demonstram uma atitude de submissão. A pesquisadora 
declara ser comum mulheres negras escutarem xingamentos como: "Que negra metida", "Essa negra se acha" ,"Quem essa negra pensa que é?" Jamila destaca que ao conversar com outras pessoas negras com o mesmo nível cultural, todas revelaram ter vivenciado situação semelhante. Ao relembrar a sua trajetória profissional, a participante faz a seguinte reflexão: "as pessoas se indignam por você ganhar mais do que elas e perguntam como você chegou naquela posição. Então eu acho que isso é um pouco do que eu tenho sentido e entendido melhor ultimamente."

\section{Docência universitária}

Ao serem questionadas sobre o que às impulsionou a buscar a carreira docente, as participantes comentam que este objetivo foi traçado ao longo de suas trajetórias profissionais. No entanto, elas destacam que no passado já haviam pensado na profissão docente, mas foram desestimuladas pelo estereótipo social de desvalorização da profissão de professor. Jamila conta que apesar do desejo de ensinar ter se manifestado desde a infância, foi desencorajada a buscar esta carreira. "Quando chegou a vida adulta eu tive aquele sonho cortado. "Eu hoje penso muito a esse respeito. 'Você quer ser professora? Então será pobre para sempre' (risos), 'você não vai ter salário', 'é bom você ingressar em uma outra área' Então optei por contabilidade." Niara também comenta que no inicio de sua trajetória profissional, não considerava a possibilidade de ser professora, pois para ela significava uma profissão onde os profissionais não eram bem remunerados.

Eu nunca desejei ser professora inicialmente, mas eu sempre gostei de comunicação. Quando eu fiz aqueles testes vocacionais, na adolescência, sempre dava jornalismo, publicidade ou docência. Mas eu não queria ir para a área da docência, enfim, por uma questão financeira.

Hooks (2013) assinala que a educação é percebida como uma área em crise, sendo o ensino considerado um objeto não digno de 
consideração. No entanto, a pesquisadora salienta que a sala de aula continua sendo um espaço que oferece possibilidades concretas de mudanças sociais. Ao percorrerem suas trajetórias acadêmicas, as participantes passaram a ter a docência universitária como uma possibilidade profissional. As duas relatam que foi durante o mestrado que surgiram as oportunidades de ingresso na docência em educação superior. Niara conta que em uma das disciplinas do mestrado teve contato com um colega que atuava em uma instituição de ensino superior, sendo através dele que ela conseguiu a chance de participar de um processo seletivo para atuar como docente.

No meio do mestrado, em um trabalho em grupo, um rapaz se manifestou e disse que ele era articulador da Instituição X. Eu perguntei de onde ele era e ele respondeu Porto Alegre. Então eu disse que me interessava e ele me orientou a enviar o currículo para a coordenadora. Eu mandei meu currículo e em questão de uma semana ela me chamou para fazer entrevista. E eu pensei: "ai meu Deus, chegou o meu momento!"

Jamila conta que após a conversa com o coordenador do mestrado, ela decidiu participar de um processo seletivo para professor substituto da universidade em que estudava. A partir da aprovação neste processo seletivo iniciou a sua trajetória como docente universitária. Jamila explica que neste período precisou conciliar as aulas do mestrado e o seu emprego como concursada em hospital com a docência.

Eu trabalhava no Hospital durante o dia, tinha aulas do mestrado três vezes por semana e dava aulas duas vezes por semana, duas noites por semana. Mas eu consegui (risos) terminar tudo, terminar o mestrado. Depois comecei a dar aulas e de lá pra cá eu recebi algumas indicações de diferentes faculdades. Trabalhei um pouco na Faculdade A, trabalhei um pouco na Universidade B, já trabalhei na Faculdade $C$ e eu vou avaliando os convites.

A participante comenta perceber diferenças entre a sua trajetória e a da maior parte dos docentes universitários. Segundo ela, 
a maioria dos seus colegas ingressou no curso de mestrado logo após a conclusão da graduação, sem a necessidade de conciliar o mercado do trabalho com a vida acadêmica. "Eles ingressam na faculdade e saem da faculdade sem nunca ter trabalhado. Ingressam direto em um mestrado e depois doutorado, também sem nunca ter trabalhado e aos 25 anos são doutores, passando no primeiro concurso para federal." De acordo com Jamila, apesar de perceber que este é o padrão de trajetória dos seus colegas professores, ela entende que o ingresso na carreira docente é mais difícil para a população negra. "A docência para nós negros é mais custosa em relação a isso. Eu, por exemplo: saí da faculdade já trabalhando. Então eu pesquisei dentro da minha carreira, como chegar a um nível em que eu pudesse pagar pelo mestrado, o que não era uma coisa automática."

Foi indagado às participantes se elas percebiam algum tipo de discriminação em relação à gênero e/ou raça em suas atuações como docentes. Niara relata não ter percebido nenhuma manifestação de preconceito de forma explícita: "Eu não senti nenhum preconceito por ser negra, 'descarado', 'escancarado', digamos assim." Conforme a participante, as manifestações percebidas por ela, ocorreram de forma sutil. Ela menciona a situação vivenciada em sala de aula com uma estudante branca:

Ela já havia tentado "colar" comigo[...] nunca permiti que nenhum aluno meu colasse ou que entregasse um trabalho "meia boca". [...] E eu sempre exigi muito dela e um dia ela falou com outra colega: "eu estou fazendo uma cadeira com aquela professora negra, ela é bem exigente", mas destacou ofato de eu ser negra. Acho que foi uma das primeiras vezes que eu ouvi.

Niara explica que ficou surpresa pelo fato da aluna destacar a cor da sua pele ao descrevê-la. Ribeiro (2019) observa que a linguagem é carregada de valores sociais e algumas expressões remetem ao entendimento de que ser negro é uma contraposição à algo. Neste sentido, a expressão "aquela professora negra, é bem exigente" pode sugerir que para aquela estudante, ser negra estaria em contraposição a uma professora exigente. 
Jamila afirma ter vivenciado uma atitude de discriminação nas primeiras semanas em que atuava como docente em uma instituição privada:

Era primeira ou segunda semana de aula, eu estava terminando de fechar os sistemas da aula, chegou o guarda e bateu na porta com força e disse: "a aula acabou, vai embora!" Falou aquilo ali e eu sentada na mesa do professor, ele não entendeu que eu era a professora, para ele aquilo era pouco plausível.

A participante complementa que se o funcionário percebesse imediatamente a sua posição como docente, a tratamento direcionado a ela seria diferente: "ele jamais teria falado comigo naquele tom e então eu vi o espanto desse mesmo funcionário quando ele entendeu que a professora era eu." Niara comenta que para evitar equívocos por parte dos estudantes, utiliza como estratégia de manifestar-se no espaço acadêmico: "Quando eu chego em uma turma que não é a minha, eu adoro chegar bem "tranquilona", brincando e falando: "Oi! Boa noite!"para o pessoal ver que eu sou a professora (risos)." Ribeiro (2019) comenta que as mulheres negras que circulam em espaços de poder, frequentemente são reduzidas a determinados estereótipos. A pesquisadora assinala que em ambientes profissionais mulheres não brancas podem ser confundidas com trabalhadoras que realizam atividades consideradas com menor status social, como por exemplo, copeira ou faxineira.

No entanto, Jamila e Niara também destacaram situações em que a presença de uma docente negra no meio acadêmico gerou manifestações positivas de estudantes e funcionários. Jamila conta que na mesma instituição em que foi hostilizada por um funcionário, recebeu uma manifestação positiva de outro profissional. "Eu tinha direito a utilizar o estacionamento dos professores e um dia um dos funcionários me falou que trabalhava lá há muito tempo e que era a primeira vez via uma professora negra. Ele estava muito feliz, pois também era negro." Niara também comenta sobre as manifestações positivas quando participa de eventos ou atividades acadêmicas: "Com certeza é um diferencial. Quando eu vou dar uma palestra ou eu promovo um mini-curso, 
eu vejo os olhares das pessoas, brilham os olhos. Eu percebo o pessoal comentando: que legal, uma professora negra!".

Davis (2016) salienta o valor simbólico para a população negra quando professoras afrodescendentes se fazem presentes no ambiente acadêmico. A pesquisadora declara que ao longo da história, as pessoas negras que recebem instrução acadêmica associam o conhecimento à uma batalha coletiva de seu povo pela igualdade de oportunidades. As participantes reconhecem o impacto de suas presenças na academia como forma de representatividade da população negra, pois percebem que se tornam uma referência para estudantes negros e negras. Niara conta que uma ex-aluna ao ser entrevistada por um jornal de grande circulação, a cita como referência em sua trajetória acadêmica.

Ela me surpreendeu quando eu vi a reportagem. Ela disse: "o que mais me fez permanecer e ser grata na faculdade é que a minha professora é uma universitária negra. Então aquilo me empoderou e me incentivou a continuar estudando". Aquilo me chocou! Ela sempre me valorizou, ela sempre foi uma pessoa inteligentíssima, ela é maravilhosa. Mas eu jamais tinha pensado aquilo, ela também é negra e eu pensei, que legal!

Jamila também comenta sobre os retornos positivos vindos dos estudantes, principalmente de alunos negros. Ela explica que assim como ela, muitos deles nasceram em bairros periféricos e são egressos de escolas públicas. "Se ela tem uma trajetória parecida com a minha, nascida na periferia, que estudou em escola pública, que começou a trabalhar muito cedo e que chegou lá, eu também posso!". Jamila também destaca a importância da realização de estudos sobre as mulheres negras no mercado de trabalho, o que a motivou a aceitar da conversa com a pesquisadora. "Eu achei bem interessante e por isso aceitei ter essa conversa. O que a gente precisa hoje é demonstrar e botar a cara pra bater". Silva e Euclides (2018) argumentam sobre a importância da presença de professoras negras nas universidades. No espaço acadêmico podem ser problematizadas questões atinentes à gênero e raça, entre docentes 
e estudantes. Além disso, estas mulheres subvertem a lógica das desigualdades sociais vividas pela população. Munanga e Gomes (2016) sustentam que as mulheres negras constroem suas trajetórias através de muita luta, perseverança e sabedoria, sendo uma referencia na construção de uma sociedade digna para todos.

\section{Considerações finais}

Mesmo passado mais de um século do fim da escravização no Brasil, as mulheres negras ainda sentem os reflexos deste período histórico, a dupla discriminação de gênero e raça. A aposta na educação tem sido vista como uma estratégia para combater a discriminação racial e de gênero sofrida por estas mulheres.

Com base na problematizarão desta perspectiva, a pesquisa propôs analisar o percurso de docentes negras buscando identificar os percursos percorridos pelas entrevistadas. Ao analisar os aspectos relativos à discriminação racial e de gênero presentes nos percursos profissionais das entrevistadas, verificou-se que as participantes vivenciaram atitudes discriminatórias no mercado de trabalho.

O ingresso na docência na educação superior não foi inicialmente considerado pelas participantes como uma opção de trajetória profissional. A necessidade de ingresso no mercado de trabalho ainda na graduação fez com que a docência universitária viesse a se tornar um objetivo ao longo da pós-graduação.

$\mathrm{O}$ estudo evidenciou que as docentes negras precisam constantemente demonstrar sua capacidade nos espaços em que atuam e que a presença destas mulheres no ambiente acadêmico causa estranhamento na sociedade. As entrevistadas reconhecem a importância de suas presenças no espaço universitário, podendo ser uma referência para estudantes negros e negras.

\section{Referências}


BRASIL. Lei $n^{0} 10.639$, de 9 de janeiro de 2003. Estabelece as diretrizes e bases da educação nacional, para incluir no currículo oficial da Rede de Ensino a obrigatoriedade da temática "História e Cultura AfroBrasileira", e dá outras providências. Disponível em: http:/ / www.planalto.gov.br/ccivil_03/leis/2003/110.639.htm. Acesso em: 20 ago. 2020.

BRASIL. Lei $n^{\circ} 12.711$ de 29 de agosto de 2012. Dispõe sobre o ingresso nas universidades federais e nas instituições federais de ensino técnico de nível médio e dá outras providências Disponível em: https:/ / www2.camara.leg.br/legin/fed/lei/2012/lei-12711-29agosto-2012-774113-publicacaooriginal-137498-pl.html. Acesso em: 27 maio 2020.

CARNEIRO, Sueli. Mulheres em movimento. Estudos avançados, São Paulo, v. 17, n. 49, p. 117-133, dez. 2003.

DAVIS, Angela. Mulheres, raça e classe. São Paulo: Boitempo, 2016.

GOMES, Nilma Lino. Educação, raça e gênero: relações imersas na alteridade. Cadernos Pagu, n. 6/7, p. 67-82, jan. 2010.

GOMES, Nilma Lino. Movimento negro e educação: ressignificando e politizando a raça. Educação E Sociedade, Campinas, v. 33, n. 120, p. 727-744, set. 2012.

GONCALVES, Luiz Alberto Oliveira; SILVA, Petronilha Beatriz Gonçalves e. Movimento negro e educação. Rev. Bras. Educ., Rio de Janeiro, n. 15, p. 134-158, dez. 2000.

HERMANN, Nadja. Hermenêutica e educação. Rio de Janeiro: DP\&A editora Ltda, 2003.

HOOKS, bell. Ensinando a transgredir: educação como prática de liberdade. São Paulo: WMF Martins Fontes, 2013.

HOOKS, bell. Olhares negros: raça e representação. São Paulo: Elefante, 2019.

HOOKS, bell. Não sou eu uma mulher? Mulheres Negras e Feminismo. Tradução livre para a Plataforma Gueto. Janeiro. [online]. 2014 Disponível em: https:/ / plataformagueto.files.wordpress.com/2014/12/nc3a3o-soueu-uma-mulher_traduzido.pdf. Acesso em: 16 ago. 2020. 
INSTITUTO BRASILEIRO DE GEOGRAFIA E ESTATÍSTICA (IBGE). Censo 2018. Brasília, 2019. Disponível em: http:/ / www.ibge.gov.br/home/. Acesso em: 20 maio 2020.

INSTITUTO NACIONAL DE ESTUDOS E PESQUISAS EDUCACIONAIS ANÍSIO TEIXEIRA (INEP). Censo de educação superior 2018. Brasília, 2019. Disponível em: http:/ / portal.inep.gov.br/. Acesso em: 20 maio 2020.

MARQUES, Eugenia Portela de Siqueira. O acesso à educação superior e o fortalecimento da identidade negra. Rev. Bras. Educ., Rio de Janeiro, v. 23, p. 1-23, dez. 2018.

MUNANGA, Kabengele; GOMES, Nilma Lino. O negro no Brasil de hoje. São Paulo: Global, 2016.

RIBEIRO, Djamila. O que é lugar de fala? Belo Horizonte, MG: Letramento, 2017.

RIBEIRO, Djamila. Pequeno manual antirracista. São Paulo: Shwarcz, 2019.

RIBEIRO, Djamila. Quem tem medo do feminismo negro? São Paulo: Shwarcz, 2018.

SCHUMAHER, Schuma; BRAZIL, Érico Vital. Mulheres negras do Brasil. Rio de Janeiro: Senac Nacional, 2007.

SILVA, Joselina da; EUCLIDES, Maria Simone. Falando de gênero, raça e educação: trajetórias de professoras doutoras negras de universidades públicas dos estados do Ceará e do Rio de Janeiro (Brasil). Educ. rev., Curitiba, v. 34, n. 70, p. 51-66, ago. 2018.

SILVA, Petronilha Beatriz Gonçalves e; GOMES, Nilma Lino (Org.). Experiências étnico-culturais para a formação de professores. 3. ed. São Paulo: Autêntica, 2007. 